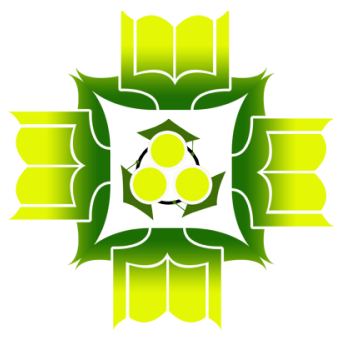

\title{
ESTABLISHMENT OF RELIGIOUS TOLERANCE THROUGH MULTICULTURAL SCHOOL CULTURE IN TAMAN HARAPAN ELEMENTARY SCHOOL MALANG CITY
}

\author{
Fita Mustafida \\ Universitas Islam Malang \\ fita.mustafida@unisma.ac.id \\ Lia Nur Atiqoh Bela Dina \\ Universitas Islam Malang \\ lia.nur@unisma.ac.id
}

\begin{abstract}
This paper aims to provide an overview of the formation of attitudes of religious tolerance through a multicultural school culture at Taman Harapan Elementary School, Malang City. The research approach used is qualitative with a case study type. Data collection techniques using participant observation, interviews, and document studies. The data analysis technique used the Huberman model analysis technique. Namely, through the stages of condensation, data presentation, concluding / verification. The results of this study indicate that the formation of religious tolerance in Taman Harapan Elementary School, Malang City, is formed through the multicultural school culture that is developed. The multicultural school culture is in question in all aspects of school community life, starting from the teaching and learning process activities in the classroom to the habituation program that is the flagship of Taman Harapan Elementary School. The process of forming an attitude of religious tolerance through school culture at Taman Harapan Elementary School, Malang City, among others, is through introducing the values of diversity such as facilities for places of worship for six religions, celebration of multi-religious holidays. Second, strengthening tolerance material in the learning. Third, habituation of the culture of religious tolerance through multicultural social interactions
\end{abstract}

Keywords: Attitude Formation, Religious Tolerance, Multicultural School Culture 


\begin{abstract}
Abstrak
Penelitian ini bertujuan untuk memberikan gambaran tentang pembentukan sikap toleransi beragama melalui budaya sekolah multikultural di SDN Taman Harapan Kota Malang. Pendekatan penelitian yang digunakan adalah kualitatif dengan jenis studi kasus. Teknik pengumpulan data menggunakan observasi partisipan, wawancara dan dokumentasi. Teknik analisis data menggunakan teknik analisis model Huberman. Yakni, melaluitahapan pemadatan, penyajian data, penyimpulan/ verifikasi. Hasil penelitian ini menunjukkan bahwa pembentukan toleransi beragama di SD Taman Harapan Kota Malang terbentuk melalui budaya sekolah multikultural yang dikembangkan. Budaya sekolah multikultural dipertanyakan dalam semua aspek kehidupan masyarakat sekolah, mulai dari kegiatan proses belajar mengajar di kelas hingga program pembiasaan yang menjadi unggulan SD Taman Harapan. Proses pembentukan sikap toleransi beragama melalui budaya sekolah di SD Taman Harapan Kota Malang antara lain melalui pengenalan nilainilai kebhinekaan seperti fasilitas tempat ibadah enam agama, perayaan hari besar multi agama. Kedua, penguatan toleransi materi dalam pembelajaran. Ketiga, pembiasaan budaya toleransi beragama melalui interaksi sosial multikultural
\end{abstract}

Kata Kunci: Pembentukan Sikap, Toleransi Beragama, Budaya Sekolah Multikultural

\title{
INTRODUCTION
}

The development of intolerance and conflict over religious differences in society indirectly illustrates social problems contrary to religious values that teach about peace and respect for differences (Agung, 2017). Therefore, tolerance has an important position and role in giving color to diversity and harmonious life order.

Masykuri Abdilah's writing entitled "Religious Tolerance in a Democratic and Multicultural Society." emphasizes the need for tolerance values that become the agreement of all parties to foster harmony. Both in the form of (1) tolerance between adherents of a particular religion, (2) tolerance between followers of different religions, and (3) tolerance between followers of a religion and the government (Agung, 2017). This is in line with (Ali \& Noor, 2019), who believe that tolerance can stem diversity conflicts between ethnic groups, cultures, languages, and religions. Therefore, it is hoped that the tolerance of Indonesian citizens can be formed to bring back Indonesian values as the hallmark of a multicultural country. 
Realizing this, Taman Harapan Elementary School Malang City took real action by developing a multicultural school culture. Multicultural school culture at Taman Harapan Elementary School Malang is illustrated by multi-religious human (school community) (D/SDTH/2021), material culture such as nameplates in front of schools, classroom displays, calendars, magazines, and other attributes; the existence of multi-religious places of worship (Islam-Mushallah, ChristianCatholic-mini church, Hindu-Pura, Buddhist-Vihara) (O/SDTH/12/2/2020). This indirectly illustrates how multicultural school culture is developed. Among others; every Friday, all students from various religions hold religious activities/ rituals, they carry out these activities in their respective places of worship that the school has provided, for Christian students perform rituals in mini churches, for Buddhist students carry out rituals at the Vihara mini, for Muslim students to perform rituals at the Musholla for girls. In contrast, male students and male Muslim teachers perform religious rituals (Friday prayers) at Jami's Mosque, Malang City (W/KS/SDTH/10/2/2021). This data is also reinforced by the researcher's observations when he was present to see the prayer room facilities at Taman Harapan Elementary School (O/Budaya/SDTH 10/2/2021).

The multicultural culture at Taman Harapan Elementary School was also evident when a school event was held (D/SDTH/2021). This activity is usually carried out at the end of the semester by holding an archipelago culinary festival and cultural performances such as dance and music. The culinary festival serves a variety of Indonesian cultural specialties ranging from Satay, Curry, Padang cuisine, Mie Aceh, Malang Meatballs, Otak-otak, Pempek, Batagor, Siomay, smoked fish, egg crust, and many more, including traditional snacks such as Klepon, Gatot, Cenil, and so on.

Interestingly, from the variety of activities, tolerance for religious teachings is very strong. This is evidenced by the labeling of each snack that is held. Such as "Sate Babi," Satay Sapi / Beef. This is done in addition to introducing the diversity of typical foods and preventing school residents from eating foods that are "forbidden" by their religion. Like pork is haram for Muslims, beef or beef is also forbidden by Hinduism (W/KS/SDTH/12-04-2021).

Some of these examples show that tolerance is a value that is upheld at Taman Harapan Elementary School. As stated by the chairman of the Taman 
Harapan Foundation on Independence Day, who always invites school members to respect each other even though we have different religions and ethnicities, with tolerance there is no more hatred between each other, on the contrary, a sense of togetherness and equality will erase thoughts negative thoughts towards other people that cause there is no unity among us (quote from the head of the Foundation's speech in the book celebrating the anniversary of SDTH).

The teaching of tolerance at SD Taman Harapan is a benchmark for how to cultivate the character of togetherness and mutual respect as the philosophy of establishing a school that promotes peace and tolerance education and is supported by the mission of developing a culture of tolerance, cooperation, and mutual respect (taken from the 2019 SDTH Anniversary book document). On this basis, it is deemed necessary to examine the formation of religious tolerance through a multicultural school culture at Taman Harapan Elementary School, Malang City, which has proven successful in forming students' religious tolerance.

\section{METHODS}

This study uses a qualitative approach (qualitative approach) with the type of case study. The research location is located at Taman Harapan Elementary School, Malang City, which is located at Jalan Aris Munandar 2-4, Kidul Dalem Village, Klojen District, Malang City. The selection of this locus is considered appropriate because Taman Harapan Elementary School is one of the schools unique as a multicultural school. It is proven by the plural school community (from various dimensions), especially the multi-religious dimension, but can respect each other (D/SDTH/2021).

The data collection of this research was conducted through participant observation, in-depth interviews, and document analysis (Patton, 2002). Participant observation was carried out with the researcher present and involved in various activities that were the subject of this research. Statements were made to understand behavioral events and attitudes shown by school residents at the research location. Through observation, the data to be obtained is about multicultural education, especially those related to the formation of attitudes of religious tolerance through multicultural school culture. In addition to observation, researchers also used in-depth interviews to obtain data. 
The interview activity involved several informants, including the principal, six classroom and religious teachers, employees, students, and parents using the Snowball Sampling strategy/according to data needs (Creswell, 2015). Interviews were conducted using a purposive technique so that the data information obtained was indeed by the objectives of this study, namely with the criteria for people who were rich in data, in the sense of understanding the conditions in the research and the locus under study. For the interview to be focused, the main structure of the questions (interview guidelines) was prepared. Interviews are conducted informally to get natural results and develop according to needs. To support the data from observations and interviews, the researchers also used document studies to keep the two previous data. Documents are needed to strengthen and provide concrete evidence of the data obtained. The document analysis process is carried out by comparing the documentation data from the researcher with the data obtained from the school. Such as supporting documents related to academic habituation/habituation activities that have multicultural values.

This study uses data analysis techniques through the stages of condensation, data presentation, conclusion drawing/verification (Miles, M.B, Huberman, A.M, dan Saldana, 2014). Condensation is carried out by analyzing the data collected from observations, interviews, and documentation that are relevant to answer the focus under study. Through this analysis, the relevant data is then displayed for exposure to research activities to find answers or conclude the findings of the research focus formulation. The process of data collection and analysis was carried out for approximately eight months.

The three paths are a unity that has existed since before, during the process, and after data collection in a parallel form as a continuous, repetitive, and endless interactive cycle and interactive. To unravel the bias of the research data obtained, check the validity of the data by using the source triangulation method or cross-checking the data obtained from research informants sources such as information from teachers to be compared with data from school principals, students, employees, and parents. While method triangulation is carried out to see how far the consistency of the data from the three data obtained (observations, interviews, and documentation) related to data or information findings in the field, then the temporary findings from the results of the data analysis are 
discussed with theoretical results both supporting and rejecting (pros and cons) to classify and draw conclusions/verification.

\section{RESULTS AND DISCUSSION}

\section{The multicultural side of Taman Harapan Elementary School}

The formation of religious tolerance in Taman Harapan Elementary School, Malang City, is found in the philosophy of school establishment. This philosophy is then used as the basis for preparing the school's vision and mission. The image contains the most fundamental statements regarding values, hopes, and goals for future school success (Dini Dwi Yustia Puteri, 2020). Therefore, the vision and mission of the school are the keys to success, considering its function as the main guideline that underlies all school programs. The idea of Taman Harapan Elementary School is the realization of a generation that is faithful, devoted, virtuous, intelligent, skilled, disciplined, and accomplished. This vision provides direction and encourages school members to realize good performance and appreciate other people's cultures. This is in line with the purpose of education which is to form a noble and character person (Thoif, 2018).

Based on the vision of the Taman Harapan Elementary School, Malang City, the entire academic community takes care of values . It is committed to continually maintaining and developing values that can be used to carry out activities. The mission of freedom, justice, equality, and protection of human rights is clearly illustrated in the description of the mission of the Taman Harapan Elementary School, including 1) Developing religious attitudes and behaviors in the environment inside and outside the school. 2) Develop a reading culture, curiosity, tolerance, cooperation, mutual respect, discipline, honesty, hard work, creativity, and independence. 3) Creating a safe, beautiful, clean, and comfortable school environment. 4) Creating a learning atmosphere that is challenging, fun, communicative, and democratic. 5) Strive for the use of study time, physical and human resources to provide the best results for the development of students. 6) Instilling social and environmental care, peace, love for the homeland, national spirit, and democratic life. 7) Improve the professionalism of educators and education staff. 8) Produce qualified graduates and have a national perspective (D/vision-mission/SDTH/ p.19). 
The mission is thick with multicultural education's ideology and values that prepare students to learn actively towards a standard structure within the school organization through empowerment and self-development (Agus Munadlir, 2016). The views of inclusiveness and tolerance are clearly illustrated from the description of the vision and mission above. Therefore, it is no exaggeration if Taman Harapan Elementary School is an elementary school institution that is the driving force in implementing multicultural education with the concept of a multicultural school that upholds the values of religious tolerance. Through this concept, all activities of school life are processed and run so that it becomes a multicultural culture.

The availability of learning and worship facilities and infrastructure that accommodates the diversity of students is one proof of the existence of multicultural cultural elements (O/SDTH/7/2/2021). Tolerance, courtesy, and character are also important concerns in the principles of providing education at Taman Harapan Elementary School. This statement is evidenced by the condition of schools that are open to accepting students from all legal religions in Indonesia, ranging from Islam, Christianity, Catholicism, Hinduism, Buddhism, and Confucianism (D/ SDTH/2021). Until now, Taman Harapan Elementary School has students who embrace six different religions. Among them; Muslim students (46), Catholics (37). Christian (111), Hindu (10), Buddhist (16), and Confucian (2) students out of a total of 222 students. (D/SDTH/2021). The existence of places of worship for all religions and religious teachers of different religions according to the students' religion is clear evidence of the development of an academic culture based on multicultural values. The formation of religious tolerance in Taman Harapan Elementary School, Malang City, is found in the philosophy of school establishment. This philosophy is then used as the basis for preparing the school's vision and mission. The vision contains the most basic statements regarding values, hopes, and goals for future school success (Dini Dwi Yustia Puteri, 2020). Therefore, the vision and mission of the school are the keys to success, considering its function as the main guideline that underlies all school programs. The vision of Taman Harapan Elementary School is the realization of a generation that is faithful, devoted, virtuous, intelligent, skilled, disciplined, and accomplished. This vision provides direction and encourages school members to realize good performance and appreciate other people's cultures. This is in line with the purpose of education which is to form a noble and character person (Thoif, 2018). 
Based on the vision of the Taman Harapan Elementary School, Malang City, the entire academic community takes care of values. It is committed to continually maintaining and developing values that can be used to carry out activities. The mission of freedom, justice, equality, and protection of human rights is clearly illustrated in the description of the mission of the Taman Harapan Elementary School, including 1) Developing religious attitudes and behaviors in the environment inside and outside the school. 2) Develop a reading culture, curiosity, tolerance, cooperation, mutual respect, discipline, honesty, hard work, creativity, and independence. 3) Creating a safe, beautiful, clean, and comfortable school environment. 4) Creating a learning atmosphere that is challenging, fun, communicative, and democratic. 5) Strive for the use of study time, physical and human resources to provide the best results for the development of students. 6) Instilling social and environmental care, peace, love for the homeland, national spirit, and democratic life. 7) Improve the professionalism of educators and education staff. 8) Produce qualified graduates and have a national perspective (D/vision-mission/SDTH/ p.19).

The mission is thick with multicultural education's ideology and values that prepare students to learn actively towards a standard structure within the school organization through empowerment and self-development (Agus Munadlir, 2016). The views of inclusiveness and tolerance are clearly illustrated from the description of the vision and mission above. Therefore, it is no exaggeration if Taman Harapan Elementary School is an elementary school institution that is the driving force in implementing multicultural education with the concept of a multicultural school that upholds the values of religious tolerance. Through this concept, all activities of school life are processed and run so that it becomes a multicultural culture.

The availability of learning and worship facilities and infrastructure that accommodates the diversity of students is one proof of the existence of multicultural cultural elements (O/SDTH/7/2/2021). Tolerance, courtesy, and character are also important concerns in the principles of providing education at Taman Harapan Elementary School. This statement is evidenced by the condition of schools that are open to accepting students from all legal religions in Indonesia, ranging from Islam, Christianity, Catholicism, Hinduism, Buddhism, and 
Confucianism (D/SDTH/2021). Until now, Taman Harapan Elementary School has students who embrace six different religions. Among them; Muslim students (46), Catholics (37). Christian (111), Hindu (10), Buddhist (16), and Confucian (2) students out of a total of 222 students. (D/SDTH/2021). The existence of places of worship for all religions and religious teachers of different religions according to the students' religion is clear evidence of the development of an academic culture based on multicultural values.

\section{Formation of religious tolerance and its urgency}

The process that initiates the formation of attitudes is the presence of objects around the individual to provide a stimulus for attitude change. (Azwar, 2015). Describes the attitude-forming factors into several things: the formation of attitudes through an intense experience process, the construction of perspectives through the influence of others, the power of culture, mass media, educational institutions, and religious institutions, the result of emotional factors. This form of tolerance is further strengthened by the policy that there is no compulsion in religion as stated in verse which means "There is no compulsion to (enter) religion (Islam); Verily, the right path is clearer than the misguided path" (Surah al-Baqarah: 256). According to Salim, the principles are (1) freedom of religion, (2) respect and the existence of religion, and (3) agree and disagreement. High awareness of existing differences will foster an attitude of tolerance (Fita Mustafida, 2020b).

Based on the description above, attitudes can be formed and need to be created to become good attitudes by religious advice and life in society. In this case, the need to include an attitude of religious tolerance is essential for every individual who develops so that children have an open or inclusive attitude towards diversity. In addition, religious tolerance is also an attitude that is very necessary for people and nations that have many religions like Indonesia. How not? Almost all religions in the world grow and develop in Indonesia. If this nation's generation does not have an attitude of religious tolerance, it will be a threat in the future that can divide the unity of this nation. In the third precept, Indonesian unity implies unifying all forms of differences, including ethnicity, religion, language, and culture. Therefore, the attitude of religious tolerance needs to be given as early as possible to children. 


\section{Multicultural school culture}

Talking about multicultural school culture, it cannot be separated from the term culture and multicultural. Culture has a close relationship with the principles and history and the vision and mission developed by the school, while multiculturalism is taken from the ideology of multiculturalism. That is an ideology that puts equality in indifference. This ideology recognizes the reality of vast cultural diversity, including traditional diversity such as ethnic, racial, or religious diversity, as well as the diversity of life forms (subcultures) that continue to emerge at every stage of the history of people's lives, both vertically and horizontally (Parekh, 2008).

From an organizational perspective, school culture is interpreted into several meanings - first, school culture is an action, namely the beliefs and goals shared by the school community. For example, in educational institutions, this culture is in the form of greeting each other, mutual respect, tolerance, and so on. Second, school culture is defined as a behavioral norm, which is a way that is commonly used in an organization that lasts a long time because all its members pass the behavior on to new members. In educational institutions, this behavior includes enthusiasm always to study hard, always maintaining cleanliness, speaking politely, and various other noble behaviors (Daryanto \& Mohammad Farid, 2013). From this understanding, what is meant by multicultural school culture is a set of patterns of values, rules, principles, traditions, and habits that are built-in schools where the regulations in question cannot be separated from the ideology of recognition and respect for diversity (multiculturalism).

Each school has a variety of activities and learning programs that are different from one another. These differences indirectly shape the behavior culture of the school community and become a distinctive school culture. According to (Zamroni, 2011), school culture is a set of value patterns, rules, principles, and traditions, which are believed and have implications for the behavior of school residents.

Multicultural school culture illustrates how the school community can live together in harmony and peace even though it is formed from individuals from different backgrounds as stated (Fita Mustafida, 2020a). That the essence of multicultural school culture is a set of patterns of values, rules, principles, 
traditions, and habits that are built-in schools that are based on the ideology of recognition and respect for diversity (multiculturalism) so that this culture is a characteristic that distinguishes it from other school cultures.

\section{Formation of religious tolerance through multicultural school culture}

The results of the search and data analysis on the formation of religious tolerance attitudes in Taman Harapan Elementary School Malang City show an essential component that plays a role in shaping students' religious tolerance, namely multicultural school culture (W/KS/SDTH/16/3/2021). The formation of religious tolerance through multicultural school culture at Taman Harapan Elementary School Malang is illustrated by the following academic activities:

\section{Introduction to the value of diversity}

The introduction of the value of diversity at Taman Harapan Elementary School in Malang has been cultivated since its establishment (W/KS/SDTH163-2021). The importance of diversity is introduced through material culture enshrined in a large sign that reads (multi-ethnic-religious school), which is placed in front of the school, which is located on Jl. Aries Munandar (D/SDTH/2021). This fact is clear evidence of the institution's commitment to introducing diversity to the community through openness to variety. In addition to the nameplate, there are also class displays, calendars, magazines, and other attributes; multireligious places of worship (Islam-Mushallah, Christian-Catholic-mini church, Hindu-Pura, Buddhist-Vihara)(O/SDTH/12/2/2021).

The introduction of diversity at Taman Harapan Elementary School is also carried out through routine school programs in multi-religious holidays (Islam, Hinduism, Buddhism, Christianity, Catholicism, and Confucianism). This can be proven by when Muslims carry out the fasting worship of Ramadan, students, and teachers, and employees who do not carry out fasting worship can respect each other. (W/BS/KS/SDTH/16-0832021). The moment of halal bi halal has also become a tradition of Taman Harapan Elementary School during the Eid celebration event. Halal bi halal is not only intended for Muslim students, but all school residents participate in these halal bi halal activities. This certainly illustrates how the school's activities for religious tolerance in Taman Harapan 
Elementary School Malang City. The cooperation of the school evidence this to prepare and organize a halal bi halal event for the academic community of Taman Harapan Elementary School, where some teachers and employees are not Muslim (D/SDTH/2021).

The moment of celebrating Christmas is also an indicator of the development of multicultural culture at SD Taman Harapan. In the event, all elements of the school helped to revitalize the Christmas atmosphere by holding various performances and student performances, such as drama, singing, sunshine, choir, and sharing of gifts and gifts. The beauty of tolerance at the Christmas event can be seen in the involvement of teachers, students, and parents in preparing Christmas celebrations. Among them by decorating the Christmas tree together. According to one teacher, this tradition has been carried out for a long time and always has been because it is a school tradition or culture (D.SDTH.2020). During Eid, they usually also make paper ketupat or decorations and others. In fact, with this background, students can work well together to strengthen social relations.

The habituation program to introduce diversity to Taman Harapan Elementary School students in Malang is carried out with various activities, including character-building activities for students, which are carried out routinely, spontaneously, and by example.

Table 1. The habituation program for Taman Harapan Elementary School students

\begin{tabular}{|c|c|c|}
\hline Routine & Spontaneous & Exemplary \\
\hline Ceremony & Get used to queuing & Dress neatly \\
\hline Gymnastics & Greeting & Giving compliments \\
\hline $\begin{array}{l}\text { Pray before and after } \\
\text { learning }\end{array}$ & Kiss hands to parents and teachers & Be honest \\
\hline Religious activity & Throw garbage in its place & \\
\hline (worship) & & On time \\
\hline $\begin{array}{l}\text { Celebration of religious } \\
\text { holidays }\end{array}$ & discussion & $\begin{array}{l}\text { Maintain personal and } \\
\text { environmental cleanliness, } \\
\text { carry out social services. Do } \\
\text { charity to those who need help }\end{array}$ \\
\hline
\end{tabular}


The table above shows that the habituation of religious tolerance starts from the minor thing: praying before class. At the beginning of the learning activity, the teacher asked the students to pray together. In this activity, the children were seen in a ready condition. They seem to have closed their eyes, folded their right and left hands; some are holding hands, some are holding their hands up, holding their arms on a bench, and placing their right hand on their left hand in front of their chest (according to the religious habits/beliefs of each student). This phenomenon shows that schools give students the freedom to behave according to their spiritual practices at home. Through these activities, tolerance for each other is evident. Awareness of multi-religious worship continues to be encouraged to form religious attitudes for Taman Harapan Elementary School residents. Understanding of worship can be seen from the perseverance of Taman Harapan Elementary School residents in carrying out religious services. For example, when it is time for prayer, the children immediately rush to the prayer room to pray in the congregation.

For those of other religions, when students worship in their respective worship rooms, it can also be seen that. However, it is not done routinely every day as Muslims are; every Friday, all students perform religious rituals in their respective places of worship. In these activities, the children seemed solemnly involved in religious activities so that all could carry out solemnly.

Some examples of these religious activities prove that the value of diversity is essential given to school residents, especially students, to foster an attitude of tolerance between religious communities (Arsyad, 2020). And what further strengthens is that Taman Harapan Elementary School is a unique locus on implementing multicultural education where tolerance grows and thrives on forming an attitude of religious tolerance for the academic community at Taman Harapan Elementary School. Many religious activities require a particular religion (Islam, Christianity, Hinduism, Buddhism, and Confucianism). Still, they are managed jointly by teachers and employees at Taman Harapan Elementary School, even though they have different religious identities. In these activities, elements of teachers and employees helped run the activities. Such as assisting in committees, preparing facilities, and others (W.KS.SDTH.2021). 
This shows that the Taman Harapan Primary School in Malang City upholds the equal rights of all religions. That is placing religious groups with one another in the same position, and they do not feel discriminated against so that an open relationship is established (Fatah, 2012). In other words, the tolerance attitude of the Taman Harapan Elementary School residents is not just passive tolerance that respects differences in fact, but active tolerance, namely tolerance that involves oneself with others amid differences and diversity. It would even be more appropriate if, apart from introducing differences, Taman Harapan Elementary School also teaches to love differences.

This concept needs to be taught because differences can be maintained with love. Loving differences can bring a sense of security and peace in their lives and lead and guide humanity towards the happiness of physical and spiritual life (I Komang Suastika Arimbawa, 2019). This is why Taman Harapan Elementary School introduces the value of diversity (diversity) to students to accept differences gracefully and love differences because differences are gifts from God that they must be grateful for.

\section{Strengthening religious tolerance material through learning}

Religious tolerance as one of the primary keys to fostering diversity is an important material to teach students. At the Taman Harapan Elementary School, cultivating an attitude of tolerance is also carried out through subject learning and habituation activities, both spontaneous and programmed routines. Learning with multicultural nuances also adorns the students' teaching and learning process journey to build a culture of religious tolerance at Taman Harapan Elementary School, Malang City. Multicultural learning in instilling the value of tolerance is widely recommended as research (Kelly, 2018) research with the title "Formation of tolerance through multicultural education at the University of Yudharta Pasuruan. And (Nurul Rahmawati, 2019) regarding "the Formation of an attitude of tolerance through learning Islamic Religious Education and character in class x students at SMKN 1 Sragen in the 2017/2018 academic year.

Indicators of learning the value of religious tolerance implemented at the Taman Harapan Elementary School in Malang City include; 1) Has the aim of forming an attitude of religious tolerance, 2) The learning material contains the values of religious tolerance. Even explicitly teaching the value of religious 
tolerance is carried out when teaching in class. The goals and expectations of education in Indonesia are to introduce and teach the character of tolerance to children through curriculum and character education content. This is relevant to the theory of implementation of multicultural learning (Banks, 2004). In line with this finding, (Hamimah, 2019) examines school culture with the title school culture research in shaping students' social piety attitudes: a multi-case study in MTs. Darussalam Ketapang Sampang and MTs. Al Falah Al-Islami found a relationship between school culture and attitude Formation.

The Formation of an attitude of religious tolerance at Taman Harapan Elementary School is also emphasized on how school residents can be open to religious issues such as respecting different ways of worshiping religions, providing opportunities for worship by religious beliefs, and also receiving direct guidance by spiritual teachers according to their respective faiths. respectively. (Fita Mustafida, 2020b). Even on certain days, also invite several religious figures to provide religious material to students (W/KS.SDTH.23-5-2021).

This is why a dialogical approach between religious communities is always carried out. According to (Roib Santoso, Fahrur Roji, 2018), dialogue aims to increase mutual understanding, not feeling successful with arguments to beat the other. The spirit sought in conversation is common values and strengths that can be used as standard guidelines or joint solutions to build healthy religious relationships and understand differences because the main essence of dialogue is transforming violent conflict into a communication culture (Subhi Azhar, 2011).

\section{Cultural habituation of religious tolerance through social interaction}

A multicultural environment is a condition wherein, in one place, there are various kinds of differences, but in it, they live together by accepting these differences (Afista et al., 2021). Many parties recognize the harmony of multireligious life at Taman Harapan Elementary School. It is a unique school that is a reference for the Chinese community in Malang City. The multicultural school culture developed in shaping attitudes of religious tolerance at Taman Harapan Elementary School builds social interaction among multicultural school members to create a social culture that is open to diversity (Fita Mustafida, 2020a). 
Multicultural culture is reflected in the interaction of school residents. Such as the interaction of teachers with different religious backgrounds with multireligious students. The teacher data analysis results show that teaching teachers at SD Taman Harapan consist of various ethnicities and religions. This is evidenced by 12 teachers being Christian, 6 being Catholic, and six being Muslim. While other religious teachers, besides Islam, Christianity and Catholicism, bring in from Hindu, Buddhist, and Confucian religious leaders when learning religion (D.SDTH.2020).

According to the Muslim, Christian, and Catholic religious teachers we met (O. 23-4-2021) religious differences at Taman Harapan Elementary School were never a problem because we were both aware that religious and ethnic differences were not reasons for not cooperating in educating the nation's children (WGSDTH.23-4-2021). This is also supported by the statement (KS/ SDTH/12-4-2021) that at SD Taman Harapan, there has never been a significant conflict due to differences in religion or ethnicity. Even the teacher always tries to provide an example or example for students. This good form is shown through; teacher performance, a polite way of speaking, thanking, apologizing, respecting the opinions of others, providing opportunities for different views, prioritizing options for older people, assigning students in turns, obeying the rules (discipline, following time, following the directions). Regulations), greets when meeting, dresses neatly and cleanly, keeps promises, rewards people who excel, behaves politely, good self-control, praises honest people, admits the truth of others, admits one's own mistakes, dares to take decisions, dare to speak the truth, protect the weak, help the poor, patiently listen to others, visit sick friends, defend the honor of the nation, return goods that do not belong to them, queue and make peace. Through this example, students can see firsthand the positive behavior shown by the teacher and imitate or imitate the teacher's attitude. At least they can foster a culture of tolerance through these figures, as stated (Erviana, 2019).

This effort aligns with the goals of multicultural education in the aspect of attitude (attitudinal goals) in the form of developing cultural awareness and sensitivity, cultural tolerance, respect for cultural identity, responsive attitude to culture, skills to avoid and resolve conflicts (Dilg, 2003). At this stage, students 
are invited to get to know each other. This effort is relevant to the concept of at-true (understanding each other), which is the gateway to implementing multicultural education. By knowing each other, we can help and complement each other. Through this introduction, children become aware that various things around them are different from them. We must respect each other's existence through these differences, not the other way around feeling that we are the best (Muhammad Nurul Bilad, 2016). This is why religious differences at SD Taman Harapan are also an asset for schools in providing knowledge and understanding to students about the existence of religious diversity in Indonesia. Through religious diversity, students can directly see and observe various other religious activities different from their religious beliefs.

Furthermore, the interaction between Muslim students and students of multi-ethnic religions was so close; they did not feel awkward even though they were of different faiths and ethnicities (O/SDTH/16.15.2021). They can mingle with other non-Muslim students who are more numerous. This is a form or form of influence from a multicultural school culture that can indirectly affect student attitudes. As the theory of social learning (Bandura, 1978), the environment influences the formation of attitudes. This is where forming an attitude of religious tolerance can be created through the influence of a person, behavior, and the environment that is integrated into a multicultural culture. This is also supported by (Mardiana, 2017). Who projects that students' attitudes can be changed through environmental learning.

Based on this explanation, it can be concluded that the multicultural social interaction at Taman Harapan Elementary School is part of the effort to form students' religious tolerance with teachers of different ethnicities and religions. So that through this interaction, the relationship between school members can be well established. There is no barrier between teachers and students, teachers are role models, and students imitate the attitudes of teachers, teachers provide security and comfort for students and uphold the values of difference. 


\section{CONCLUSION}

The description above shows that SD Taman Harapan is a school that instills religious tolerance values so that it can have a significant effect on the formation of tolerance attitudes of school residents based on the matters contained in the vision and mission, curriculum, and school culture developed. Religious diversity at Taman Harapan Elementary School is a medium for teaching more concrete values of religious tolerance. Children not only imagine but also interact directly with friends and teachers who have different religions.

The formation of religious tolerance through multicultural school culture at SD Taman Harapan Malang City is formed through the academic activities of students, among others; strengthening the value of diversity, teaching the importance of religious tolerance through multicultural social interaction, and strengthening the value of religious tolerance through learning. So it can be said that the multicultural school culture at SD Taman Harapan Malang City can be described from all school activities, social interactions to various existing activity programs. So that all these activities become a forum for developing students' character and religious tolerance through a multicultural school environment. 


\section{REFERENCES}

Afista, Y., Sumbulah, U., \& Hawari, R. (2021). PENDIDIKAN MULTIKULTURAL DALAM TRANSFORMASI LEMBAGA PENDIDIKAN ISLAM DI DI INDONESIA. Journal Evaluasi, 5(1). https:// doi.org/10.32478/evaluasi. v5i1.602

Agung, D. A. G. (2017). Keragaman Keberagaman (Sebuah Kodrati Kehidupan Berbangsa dan Bernegara Berdasarkan Pancasila). Sejarah Dan Budaya: Jurnal Sejarah, Budaya, Dan Pengajarannya, 11(2). https://doi. org/10.17977/um020v11i22017p151

Agus Munadlir. (2016). STRATEGI SEKOLAH DALAM PENDIDIKAN MULTIKULTURAL. JPSD : Jurnal Pendidikan Sekolah Dasar, 2. https:// media.neliti.com/media/publications /71532-ID-strategi-sekolahdalam-pendidikan-multik.pdf

Ali, N., \& Noor, S. (2019). Pendidikan Islam Multikultur: Relevansi, Tantangan, dan Peluang. Jurnal Hadratul Madaniyah, 6(1). https:/ / doi.org/10.33084/ jhm.v6i1.879

Arsyad, A. R. (2020). PEMAHAMAN KEBHINEKAAN PESERTA DIDIK DI MADRASAH ALIYAH (STUDI KASUS MAN 1 MAKASSAR DAN MAN 2 BULUKUMBA). EDUCANDUM, 6(2). https://doi.org/10.31969/ educandum.v6i2.411

Azwar. (2015). Sikap manusia dan teori pembentukannya. Pustaka Pelajar.

Bandura, A. (1978). Social Learning Theory of Aggression. Journal of Communication. https://doi.org/10.1111/j.1460-2466.1978.tb01621.x

Banks, J. A. (2004). Teaching for social justice, diversity, and citizenship in a global world. Educational Forum. https:/ / doi.org/10.1080/00131720408984645

Creswell, W. J. (2015). Penelitian Kualitatif dan Desain Riset: Memilih diantara Lima Pendekatan. Pustaka Pelajar.

Daryanto \& Mohammad Farid. (2013). Konsep Dasar Manajemen Pendidikan di Sekolah. Gava Media. 
Dilg, M. (2003). Thriving in the multicultural classroom: Principles and practices for effective teaching. In Multicultural Education Series.

Dini Dwi Yustia Puteri, P. (2020). RUMUSAN VISI MISI DAN KONSISTENSINYA TERHADAP KULTUR SEKOLAH. INTELEKTIVA : JURNAL EKONOMI, SOSIAL \& HUMANIORA, 2.

Erviana, R. (2019). Peran Guru PAI Dalam Menerapkan Pendidikan Multikultural Terhadap Pengembangan Sikap Toleransi Siswa di SMP Cahaya Bangsa Metro [INSTITUT AGAMA ISLAM NEGERI METRO (IAIN) METRO]. https:/ / repository.metrouniv.ac.id/id/eprint/423/

Fatah, A. (2012). BUDAYA TOLERANSI DALAM PEMBELAJARAN PENDIDIKAN AGAMA ISLAM. UNIVERSITAS ISLAM NEGERISYARIF HIDAYATULLAH JAKARTA.

Hamimah. (2019). Budaya Sekolah dalam membentuk sikap Kesalehan Sosial Siswa: studi multi kasus di MTs. Darussalam Ketapang Sampang dan MTs. Al Falah Al Islami Jrengik Sampang Madura [Universitas Islam Negeri Sunan Ampel Surabaya]. http:/ / digilib.uinsby.ac.id/32627/

I Komang Suastika Arimbawa. (2019). MEMBANGUN KERUKUNAN MELALUI KONSEP ESOTERISME DALAM TEKS TUTUR JATISWARA (STUDI FILSAFAT PERENNIAL. JURNAL SANJIWANI, X. http://www. ejournal.ihdn.ac.id/index.php/Sanjiwani/article/view/1520/1194

Kelly, E. (2018). Pembentukan Sikap Toleransi Melalui Pendidikan Multikultural Di Universitas Yudharta Pasuruan. Jurnal Psikologi, 5(1).

Mardiana, D. (2017). INTERNALISASI NILAI ETIKA LINGKUNGAN DI SEKOLAH DASAR. JURNAL SOSIORELIGI, 15. https://ejournal.upi. edu/index.php/SosioReligi/article/view/5622/3815

Miles, M.B, Huberman, A.M, dan Saldana, J. 2014. (2014). Qualitative Data Analysis, A Methods Sourcebook, Edition 3. Sage Publications.

Muhammad Nurul Bilad. (2016). Konsep Pendidikan Multikultural dalam Perspektif Ibnu Katsir dan Tafsir al Misbah (analisis surat al hujurat ayat 13) [Universitas Islam Negeri Maulana Malik Ibrahim Malang]. http://etheses.uinmalang.ac.id/10382/1/11110153.pdf 
Mustafida, Fita. (2020a). Integrasi Nilai-nilai Multikultural dalam Pembelajaran Pendidikan Agama Islam (PAI). Jurnal Pendidikan Islam Indonesia. https:/ / doi.org/10.35316/jpii.v4i2.191

Mustafida, Fita. (2020b). Pendidikan Islam Multikultural (konsep dan implementasi proses pembelajaran PAI berbasis nilai-nilai multikultutral). Rajawali Press.

Nurul Rahmawati, M. M. (2019). PEMBENTUKAN SIKAP TOLERANSI MELALUI PEMBELAJARAN PENDIDIKAN AGAMA ISLAM DAN BUDI PEKERTI PADA SISWA KELAS X DI SMK N 1 SRAGEN TAHUN AJARAN 2017/2018. Edukasi Islami (Jurnal Pendidikan Islam), 8(1). http:/ / jurnal.staialhidayahbogor.ac.id/index.php/ei/article/view/309

Parekh, B. (2008). Rethinking Multiculturalism (keberagaman Budaya dan Teori politik). Kanisius.

Patton, M. Q. (2002). Nontraditional Regulations, and Innovations in DarningCentered, Doctoral Education, Including Faculty Meetings That Are Interesting and Important, an Indication of Knovation of the Highest Order. In Qualitative Inquiry. http://books.google.com/books/about/ Qualitative_research_and_evaluation_meth.html?id=FjBw2oi8E14C

Roib Santoso, Fahrur Roji, M. F. Z. (2018). PENGEMBANGAN PENDIDIKAN MULTIKULTURAL MELALUI DIALOG ANTAR UMAT BERAGAMA PERSPEKTIF AL-QUR'AN DAN HADITS. Jurnal Kajian Hukum Islam, 5(2). https://garuda.ristekbrin.go.id/documents/detail/1004113

Subhi Azhar. (2011). "Rethinking Dialogue: Antara Konflik Dan Perubahan Damai,." Harmoni, 10.

Thoif, M. (2018). ANALISIS KEBIJAKAN UU NO. 20 TAHUN 2003 TENTANG SISDIKNAS. Jurnal Kependidikan Dan Keagamaan.

Zamroni. (2011). Pendidikan Demokrasi pada Masyarakat Multikultural,. Gavin Kalam Utama. 
